\title{
In vitro Phytochemical Investigation of Helianthus annuus Seeds
}

\author{
Rubab Tarannum Islam, Mir Monir Hossain, Dr. Kishor Majumder and \\ Amjad Hossain Tipu
}

\author{
Department of Pharmacy, University of Science and Technology Chittagong (USTC)
}

Received: June 06, 2015; Accepted: June 28, 2015; Published (Web): February 17, 2016

\begin{abstract}
The seeds of Helianthus annuиs have been investigated for the presence of various chemical components and biological activities with special emphasis to the anti-oxidant, antimicrobial, cytotoxic and thrombolytic assay. The results of standard phytochemical analysis revealed the presence of tannins, saponins, flavonoids, carbohydrates, steroids, fixed oils and vitamins. In vitro antioxidant activity of methanolic seed extract of $H$. annuиs was determined by DPPH free radical scavenging assay, which demonstrated very significant antioxidant potential compared to standard antioxidant (ascorbic acid). In case of antimicrobial assay, the methanolic and ethyl acetate extract of $H$. annuus seeds showed high sensitivity to Salmonella typhi and moderate sensitivity to Pseudomonous aeuregenosa. The petroleum ether extract revealed high sensitivity to $P$. aeuregenosa. The methanolic extract of $H$. annuиs displayed $\mathrm{LC}_{50} 1.2 \mathrm{ug} / \mathrm{ml}$ and its petroleum ether extract showed $\mathrm{LC}_{50}$ of $1.1 \mathrm{ug} / \mathrm{ml}$, which indicated significant cytotoxicity.
\end{abstract}

Key words: Helianthus annuus, DPPH scavenging activity, antioxidant, cytotoxity

\section{Introduction}

The sunflower seed is the fruit of Helianthus annuus, belonging to the family Asteraceae. Sunflower seeds are usually classified by the pattern of their husks. If the husk is solid black, the seeds are called black oil sunflower seeds. The crops may be referred to as oilseed sunflower crops. These seeds are usually pressed to get the oil. Striped sunflower seeds are primarily used for food; as a result, they may be called confectionery sunflower seeds. It is a potential protein supplement for human diet, due to its good nutritional content and the absence of any antinutritional factors. However, the primary use of sunflower seed is not for edible protein. Rather it is for the oil because certain attributes of sunflower seed oil are particularly attractive to the food industries. It is a rich source of vitamins, especially vitamin $\mathrm{E}$.

Microorganisms like Staphylococcus aureus and Pseudomonas aeuregenosa are the common pathogens of human infection. S. aureus is an opportunistic pathogen of human skin. P. aeuregenosa is a pathogen associated with pyrogenic infection and urinary tract problems. These microorganisms are highly pathogenic and the rate of infection caused by these microorganisms is considerably increasing in recent years. Hence, the use of plant products has been increasing worldwide, to minimize side effects.

Antioxidants are considered important nutraceuticals on account of many health benefits. The requirement of a standard assay is very important in order to compare the results of different laboratories and validation of the conclusions. 1,1-Diphenyl-2picryl-hydrazyl (DPPH) is a stable free radical which has an unpaired valence electron at one atom of nitrogen bridge. Scavenging of DPPH radical is the basis of the popular DPPH antioxidant assay. Due to simplicity, flexibility and high throughput, TLC technique may be used for qualitative antioxidant test.

The brine shrimp lethality bioassay is a rapid and comprehensive bioassay for the bioactive compounds. In this method, in vivo lethality in brine shrimp nauplii is used as a favorable monitor for screening and

Correspondence to: Rubab Tarannum Islam; Mobile: 01710273508; E-mail: tarannum.islam508@ gmail.com 
fractionation in the discovery of new bioactive products. It indicates cytotoxicity as well as a wide range of pharmacological activities such as antimicrobial, antiviral, pesticidal anti-tumor, etc. Generally the $\mathrm{LD}_{50}$ values for cytotoxicities are one tenth of $\mathrm{LC}_{50}$ values in the brine shrimp lethality test.

\section{Materials and Methods}

Collection of seeds: The air dried seeds of $H$. annuиs were collected at their matured state from Bangladesh Agriculture Research Institute, Gazipur, Bangladesh in June 2014. Undesired plant parts or additives were removed after the collection. Then these were air dried in absence of sun light for several days. The seeds were ground into a coarse powder with the help of electric grinder. The powder was stored in air tight container and placed in a cool, dry and dark place.

Preparation of extract: $300 \mathrm{~g}$ of dried powder was taken in an aspirator $(2.5 \mathrm{~L})$. Before placing powder into the aspirator, the jar was washed properly with acetone and then dried. $800 \mathrm{ml}$ of solvent i.e. methanol was added gradually. The container with its content was sealed and kept for 20 days with occasional shaking and stirring. The major portion of the extractable compounds of the seeds was dissolved in the solvent. Then whole mixture was filtered through cotton wool and the filtrate was concentrated by evaporation in dry and clean air. The entire process was repeated using ethyl acetate and petroleum ether as the solvent to obtain ethyl acetate and petroleum ether extracts. But here $225 \mathrm{~g}$ of dried seed powder was taken with $675 \mathrm{ml}$ of ethyl acetate and petroleum ether separately. The extraction was continued for 15 days. The seeds of $H$. annuиs were extracted in different solvents to make the study more relevant and efficient.

Phytochemical screenings: Phytochemical screenings were performed to investigate the presence of various chemical components present in the seeds. Different types of tests were performed for the screening of alkaloids, glycoside, flavonoids, terpenoids, etc as shown below:

\begin{tabular}{lll}
\hline Phytochemicals & Test & Inference \\
\hline Carbohydrates & Fehling's test & + \\
Alkaloids & Wagner's test & + \\
Flavonoids & Alcoholic test & + \\
Tannins & Ferric chloride test & - \\
Glycosides & Keller-Killiani test & - \\
Saponins & Foam test & - \\
Steroids & Libermann-Burchard test & + \\
Triterpenoids & Libermann-Burchard test & + \\
Gum & Molisch's test & - \\
\hline
\end{tabular}

Antimicrobial activity: The in vitro antimicrobial activity of the methanol, ethyl acetate and petroleum extracts obtained from the seeds of $H$. annuus was determined. Three pathogenic bacteria were used as test organisms for antibacterial activity of the dried extracts. The antimicrobial activity was determined by using the standardized disc diffusion method (Zavala et al., 1997; Md. Kamal Hossain et al., 2012). Antibacterial activity was evaluated by measuring diameter of zone of inhibition (in millimeters) of bacterial growth (Zavala et al., 1997; Baver et al., 2001 and Barrett et al., 2003). The bacterial strains were collected from the Microbiology Laboratory of BCSIR, Chittagong, Bangladesh. Nutrient agar media was used for culture of the test organisms. Cefradine disk $(0.03 \mathrm{mg} / \mathrm{disk})$ was used as standard. For extracts $100 \mu \mathrm{g} /$ disc were used. The sample discs, the standard antibiotic discs and the control discs were placed gently on the 
previously marked zones in the agar plates, preinoculated with the test organism. The discs were then incubated on the plate aerobically at $37^{\circ} \mathrm{C}$ for 24 hours. The diameter of inhibition zone around each disc was measured and recorded at the end of the incubation period. The extract concentration able to inhibit microbial growth, which was observed through the formation of an inhibition growth zone around the disc (equal to or greater than $8 \mathrm{~mm}$ ), was considered as active.

Antioxidant activity: Flavonoids are known to be highly effective antioxidant by scavenging oxygen radical, for interesting anti-cancer, hypo lipidemic, antiageing, and anti-inflammatory activities (Giada et al., 2009; Amirul et al., 2013; Somaia et al., 2014). Moreover, the protective effects of flavonoids in biological systems are attributed to their capacity to scavenge free radicals, chelate metal catalysts, activate antioxidant enzymes, reduce alpha tocopherol radicals and inhibit oxidases (Kansci et al., 2003).

Preparation of extract solution: The antioxidant activity of seed extract was determined by in vitro method (DPPH free radical scavenging assay). The free radical scavenging capacity of the methanolic extract of H. annuus was determined using DPPH. DPPH solution $(0.004 \% \mathrm{w} / \mathrm{v})$ was prepared in methanol. The methanol extract of $H$. annuus was mixed with methanol to prepare the stock solution $(10 \mathrm{mg} / 100 \mathrm{ml})$. The concentration of this $H$. апnиus methanolic extract solution was $10 \mathrm{mg} / 100 \mathrm{ml}$. From the stock solution, 500-, 250- , 125-, 62.5-, 31.25-, 15.62-, 7.81- , 3.90- , $1.953-$ and $0.96-\mu \mathrm{g} / \mathrm{ml}$ solutions were prepared. Freshly prepared DPPH solution $(0.004 \% \mathrm{w} / \mathrm{v})$ was added in each of these test tubes containing $H$. апnииs methanolic extract and after $10 \mathrm{~min}$, the absorbance was taken at $517 \mathrm{~nm}$ using a UV-visible spectrophotometer. Ascorbic acid was used as a reference standard. The solution of petroleum ether and ethyl acetate extracts of $H$. annuиs were also prepared. Control sample was prepared without adding any extract and methanol was used as blank.

The scavenging activity of DPPH (\%) was calculated by using the following equation -

$\%$ DPPH radical scavenging $=\frac{\text { Absorbance of control }- \text { Absorbance of test sample }}{\text { Absorbance of control }} \times 100$

In antioxidant activity assays, different concentrations of seed extract were used to find out the concentrations which could induce 50\% inhibition to calculate the $\mathrm{IC}_{50}$.

\section{Cytotoxic activity}

Preparation of seawater: $38 \mathrm{~g}$ sea salt (pure $\mathrm{NaCl}$ ) was weighed, dissolved in one litre of distilled water and filtered off to get a clear solution.

Hatching of brine shrimps: Artemia salina leach (brine shrimp eggs) collected from pet shops was used as the test organism. Sea water was taken in a small tank and shrimp eggs were added to one side of the tank and then this side was covered. Two days were allowed to hatch the shrimp and to be natured as nauplii. Constant oxygen supply was carried out through the hatching time. With the help of lamp and Pasteur pipette, 10 living shrimps were added to each of the vials containing $5 \mathrm{ml}$ of sea water.
Test solutions of extracts: In a small beaker, measured amount of the sample was accurately weighed and dissolved in DMSO (Dimethyl sulfoxide) to give a final concentration of $10 \mathrm{mg} / \mathrm{ml}(10 \mu \mathrm{g} / \mu \mathrm{l})$.

Application of test sample to the test tube containing brine shrimp nauplii: 8 test tubes for the sample were taken where each contained $5 \mathrm{ml}$ of sea water and 10 nauplii. These test tubes were marked from 1 to 8 . To the test tubes, different concentration of the sample was added. In test tube 1000-, 500-, 250-, 125-, 62.5-, 31.25-, 15.625-, 7.82- and $3.91 \mu 1$ of the sample were added to test tubes to give the concentration of 1000-, 500-, 250-, 125-, 62.5-, 31.25-, $15.625-, 7.82-$ and $3.91 \mu \mathrm{g} / \mathrm{ml}$ of the sample. Then the samples were subjected to brine shrimp lethality bioassay.

Preparation of control group: Control groups are used in cytotoxicity study to validate the test method and ensure that the results obtained are only due to the 
activity of the test agent and the effects of the other possible factors are nullified. $30 \mu \mathrm{l}$ of DMSO was added to each of three pre marked glass vials containing $5 \mathrm{ml}$ of simulated sea water and 10 shrimp nauplii is used as control group. If the brine shrimps in these vials show a rapid mortality rate, then the test is considered as invalid as the nauplii died due to some reasons other than the cytotoxicity of the compounds. After 24 hours, the vials ware inspected using a magnifying glass and the numbers of survived nauplii in each vial were counted. From this data, the percent $(\%)$ of lethality of the brine shrimp nauplii was calculated for each concentration.

\section{Results and Discussion}

Results of in vitro antioxidant test: In this study, the antioxidant capacity of methanolic extract of $H$. annuus seeds and ascorbic acid was systematically evaluated. The DPPH inhibition of different plant extracts is summarized in table 1 .

Table 1. Radical scavenging activity of methanol extracts and standard antioxidant on DPPH free radical.

\begin{tabular}{lccc}
\hline Sample & $\begin{array}{c}\text { Concentration }(\mu \mathrm{g} / \mathrm{ml}) \\
\text { Mean } \pm \mathrm{SD}\end{array}$ & \% Inhibition & $\mathrm{IC}_{50}$ \\
\hline Methanol extract & $90 \pm 11.56$ & 51.57 & 0.814 \\
Ascorbic acid & $73.26 \pm 17.80$ & 46.66 & 1 \\
\hline
\end{tabular}

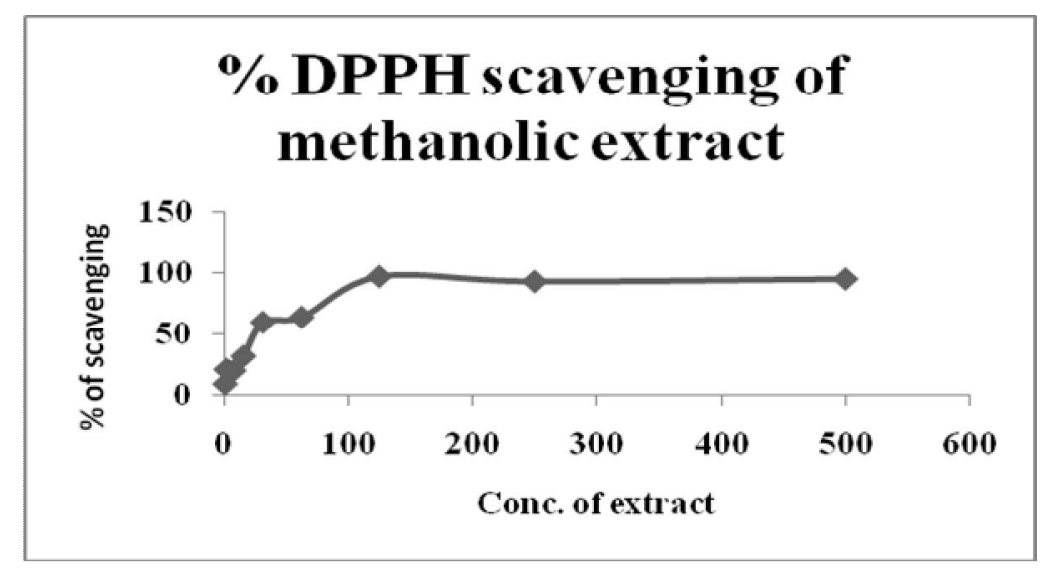

Figure 1. \% DPPH scavenging of methanolic extract.

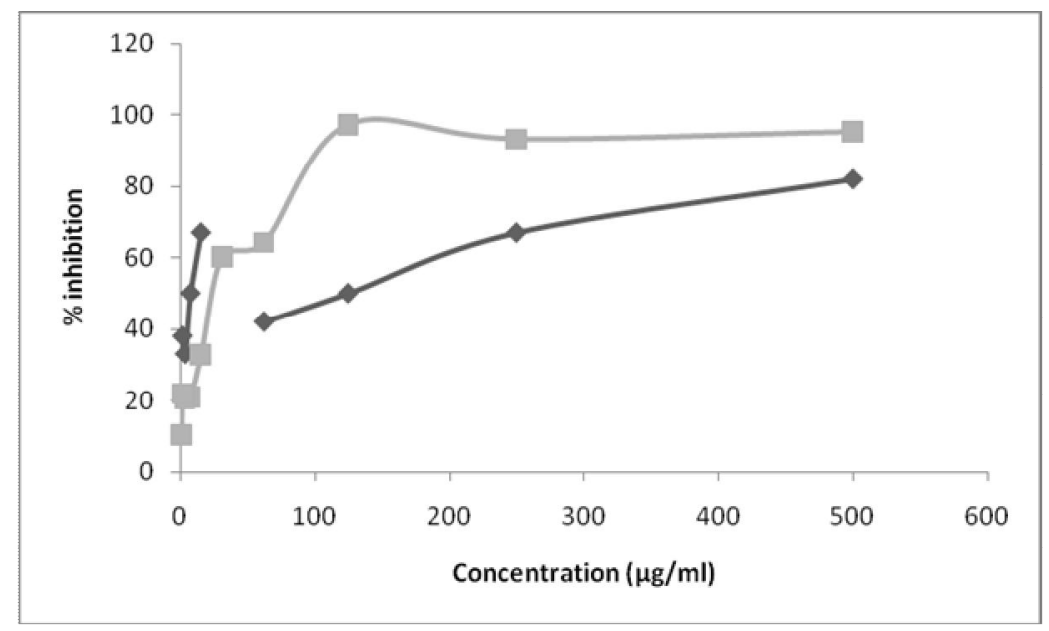

Figure 2. Comparative free radical scavenging activity of methanolic extract of Helianthus annuus with ascorbic acid (reference). 
Antioxidant activity of selected plant extract compared with standard antioxidant ascorbic acid showed that selected plants have potential antioxidant activity like ascorbic acid. Methanolic extract of $H$. annuus showed $51.57 \%$ DPPH scavenging activity and $\mathrm{IC}_{50}$ was 0.814 whereas 1.0 in case of ascorbic acid.

Results of in vitro antimicrobial test: The extract of seeds was tested for antimicrobial activity against three pathogens $S$. paratyphi, $P$. aeuroginosa and $V$. cholerea. Disk of cefradine was used as a standard for comparison purposes. The three different extracts of seeds showed antibacterial activity against some of the test organisms. The results of the antibacterial activity, measured in terms of diameter of zone of inhibition in $\mathrm{mm}$ are showed in table 2 . The zone of inhibition was found in different organisms.

Table 2. In vitro antimicrobial activity of the methanol extract of seed of $\mathrm{H}$. annuus.

\begin{tabular}{lccccc}
\hline \multicolumn{5}{c}{ Zone of inhibition } \\
\hline Name of the organism & $\begin{array}{c}\text { Methanol extract } \\
(100 \mu \mathrm{g} / \mathrm{disc})\end{array}$ & $\begin{array}{c}\text { Ethyl acetate extract } \\
(100 \mu \mathrm{g} / \mathrm{disc})\end{array}$ & $\begin{array}{c}\text { Petroleum ether extract } \\
100 \mu \mathrm{g} / \mathrm{disc}\end{array}$ & $\begin{array}{c}200 \mu \mathrm{g} / \mathrm{disc} \\
(30 \mu \mathrm{g} / \mathrm{disc})\end{array}$ \\
\hline Salmonella paratyphi & 11 & 0 & 0 & 0 & 50 \\
Pseudomonus aeuroginosa & 0 & 8.5 & 9 & 8 & 50 \\
Vibrio cholerea & 0 & 0 & 0 & 0 & 50 \\
\hline
\end{tabular}

Table 3. Brine shrimp lethality bioassay for the $\boldsymbol{H}$. annuus extract of methanol.

\begin{tabular}{llll}
\hline $\begin{array}{l}\text { Conc. of the sample } \\
(\mu \mathrm{g} / \mathrm{ml})\end{array}$ & $\%$ of mortality & $\mathrm{LC}_{50}(\mu \mathrm{g} / \mathrm{ml})$ & $\begin{array}{l}\mathrm{LC}_{90} \\
(\mu \mathrm{g} / \mathrm{ml})\end{array}$ \\
\hline 1000 & 100 & & \\
500 & 100 & 1.2 & 2.1 \\
250 & 100 & & \\
125 & 90 & & \\
\hline
\end{tabular}

Table 4. Brine shrimp lethality bioassay for the $\boldsymbol{H}$. annuus extract of petroleum ether.

\begin{tabular}{crcc}
\hline Conc. of the sample $(\mu \mathrm{g} / \mathrm{ml})$ & \% of mortality & $\mathrm{LC}_{50}(\mu \mathrm{g} / \mathrm{ml})$ & $\mathrm{LC}_{90}(\mu \mathrm{g} / \mathrm{ml})$ \\
\hline 1000 & 100 & & \\
500 & 100 & 1.11 & 2.28 \\
250 & 100 & & \\
125 & 90 & & \\
\hline
\end{tabular}

Both methanolic and petroleum ether extracts of $H$. annuus shows $100 \%$ mortality at concentration $1000 \mu \mathrm{g} / \mathrm{ml}, 500 \mu \mathrm{g} / \mathrm{ml}, 250$ $\mu \mathrm{g} / \mathrm{ml}$. The methanolic extract showed $\mathrm{LC}_{50} 1.2$ and petroleum ether extract showed $\mathrm{LC}_{50} 1.11$, which indicate significance cytotoxic activity $(\mathrm{P}<0.05)$.

The seed extract of $H$. annuus showed high sensitivity to $S$. typhi, moderate sensitivity to $P$. aeuregenosa and less sensitivity to $V$. cholerae. Petroleum ether extract of $H$. annuus showed high sensitivity to $P$. aeuregenosa.

Results of in vitro cytotoxic activity: The methanolic and petroleum ether extracts of the seeds tested showed good brine shrimp larvicidal activity.
The degree of lethality was directly proportional to the concentration of the extract.

\section{Conclusion}

The $H$. annuиs seed extracts of different solvents in this research exhibited different degrees of antioxidant activity. This study indicated that the seed may be one 
of the most effective plant parts in terms of antioxidant properties and can serve as natural sources to the free radical scavengers and antioxidant agents and as possible preventive agents of some common human health disorders. The study was designed to check the antimicrobial activity of different solvent extracts of $H$. annuиs seed against three pathogenic bacteria. The methanolic extract showed high sensitivity to $S$. typhi, $\&$ moderate sensitivity to $P$. aeuregenosa. Petroleum ether extract showed high sensitivity to $P$. aeuregenosa. As evident from this antibacterial study, seeds of $H$. annuиs may contain important chemical substances that confer upon this plant as medicinal agent possessing antibacterial activity. This information will help us to design antibiotics against the diseases cause by them. The extracts exhibited cytotoxic activity against the brine shrimp and considered as containing active or potent components. This is because of their $\mathrm{LC}_{50}$ values found as 1.11. It is very useful by providing a preliminary screening that can be supported by a more specific bioassay. Thus, some useful drugs of therapeutic importance may develop out of the research work.

\section{References}

Barrett, B., Kiefer, D. and Rabago, D. 2003. Assessing the risks and benefits of herbal medicine: an overview of scientific evidence. Altern Ther Health Med. 5, 40-49.

Bauer, A,W. et al. 2001. Antibiotic susceptibilities testing by standard single disc diffusion method. Am. J. Clin. Pathol. 45, 493-496.

Chadni, S.H., Hasan, A.A. and Azam, A.T.M.Z. 2014. Antimicrobial, cytotoxic, thrombolytic and antioxidant activities of syzygium fruticosum (Roxb.) DC. Bangladesh Pharm. J. 17, 51-54.
Giada, M.D. and Mancini-Filho, J. 2009. Antioxidant capacity of the striped sunflower (Helianthus annuus L.) seed extracts evaluated by three in vitro methods. Int. J. Food Sci. Nutri. 60, 395-401.

Hossain, M.K., Hassan, M.M., Parvin, M.N., Hasan, M.M., Islam, M.S. and Haque, M.A. 2012. Antimicrobial, cytotoxic and thrombolytic activity of Cassia senna leaves (family: Fabaceae). J. App. Pharm. Sci. 2,186190.

Islam, A., Rana, S.M.M., Das, A., Saha, M.R. and Uddin, S.M.G. 2013. In vitro antioxidant, thrombolytic and cytotoxic activities of methanolic leaf extract and its fractionates of erioglossum rubiginosum (Roxb.) blume. Dhaka Univ. J. Pharm. Sci. 12, 153-158.

Kansci, G., Dongo, E. and Genot, C. 2003. 2,2-Diphenyl-1picrylhydrazyl (DPPH) test demonstrates antiradical activity of Dorstenia psilurus and Dorstenia ciliate plant extracts . Nahrug/Food; 47, 434-437.

Khan, M.F., Shilpi, R.I., Rashid, R.B. and Rashid, M.A. 2014. In vitro antioxidant, cytotoxic and membrane stabilizing activities of Bauhinia acuminata L. Bangladesh Pharm. J. 17, 99-101.

Murray, P.R., Baron, E.J, Pfallar, M.A, Tenover, F.C. and Yolke, R.H. 2001. Manual of Clinical Microbiology, $6^{\text {th }}$ edition, Washington DC; 6, 214-215.

Roginsky, V. and Lissi, E.A. 2005. Review of methods to determine chain-breaking antioxidant activity in food. Food Chem. 92, 235-254.

Soler-Rivas, C., Espin, J.C. and Wichers, H.J. 2000. An easy and fast test to compare total free radical scavenger capacity of foodstuffs. Phytochem. Anal. 11, 1-9.

Zavala, S.M.A., Perez, G.S. and Perez, G.M. 1997. Antimicrobial screening of some medicinal plants. Phyto. Res. 11, 368-371. 